\title{
Climate change and the skiing industry in southern Ontario (Canada): exploring the importance of snowmaking as a technical adaptation
}

\author{
Daniel Scott ${ }^{1, *}$, Geoff McBoyle ${ }^{2}$, Brian Mills ${ }^{1}$ \\ ${ }^{1}$ Adaptation and Impacts Research Group, Environment Canada, at the Faculty of Environmental Studies, and \\ ${ }^{2}$ Department of Geography, Faculty of Environmental Studies, University of Waterloo, Waterloo, Ontario N2L 3G1, Canada
}

\begin{abstract}
The winter tourism industry has been repeatedly identified as potentially vulnerable to global climate change. Climate change impact assessments of ski areas in Australia, Europe and North America all project negative consequences for the industry. An important limitation of earlier studies has been the incomplete consideration of snowmaking as a climate adaptation strategy. Recognising that snowmaking is an integral component of the ski industry, this study examined how current and improved snowmaking capacity affects the vulnerability of the ski industry in southern Ontario (Canada) to climate variability and change. A $17 \mathrm{yr}$ record of daily snow conditions and operations from a primary ski area in the region was used to calibrate a ski season simulation model that included a snowmaking module with climatic thresholds and operational decision rules based on interviews with ski area managers. Climate change scenarios (2020s, 2050s, 2080s) were developed by downscaling climate variables from 4 general circulation models (using both IS92a and SRES emission scenarios) with the LARS weather generator (parameterized to local climate stations) for input into a daily snow depth simulation model. In contrast to earlier studies, the results indicate that ski areas in the region could remain operational in a warmer climate, particularly within existing business planning and investment time horizons (into the 2020s). The economic impact of additional snowmaking requirements remains an important uncertainty. Under climate change scenarios and current snowmaking technology, the average ski season at the case study ski area was projected to reduce by $0-16 \%$ in the 2020 s, $7-32 \%$ in the 2050 s and $11-50 \%$ in the 2080 s. Concurrent with the projected ski season losses, the estimated amount of snowmaking required increased by 36-144\% in the scenarios for the 2020s. Required snowmaking amounts increased by $48-187 \%$ in the scenarios for the 2020s. The ability of individual ski areas to absorb additional snowmaking costs and remain economically viable in addition to the relative impact of climate change on other nearby ski regions (Québec, Michigan and Vermont) remain important avenues of further research. The findings reveal the importance of examining a wide range of climate change scenarios and the necessity of including snowmaking and other adaptation strategies in future climate change vulnerability assessments of the ski industry and winter tourism in other regions of the world.
\end{abstract}

KEY WORDS: Climate change $\cdot$ Skiing $\cdot$ Adaptation $\cdot$ Snowmaking $\cdot$ Canada

Resale or republication not permitted without written consent of the publisher

\section{INTRODUCTION}

Weather and climate have a strong influence on the tourism and recreation sector (Perry 1997), including the physical resources that are the foundation of many recreation activities (e.g. health of coral reefs, water levels for boating, and snow cover for skiing) and the length and quality of tourism and recreation seasons. Nonetheless, a number of researchers have lamented that comparatively few investigations have assessed the relationships between climate and tourism (Wall 1992, Smith 1993, Perry 1997, de Freitas 2001 [www.uni-freiburg.de/isb]). As a consequence, the vulnerability of individual recreation industries and tourism regions to climate variability has not been adequately assessed. Despite the growing significance of the tourism industry to the global economy, Smith (1990), Wall (1992), Agnew \& Viner (2001), Maddison 
(2001), and Scott et al. (2002) expressed concern that understanding of the potentially profound impacts of global climate change on this important economic sector remains equally limited.

The winter tourism industry, in particular, has been repeatedly identified as potentially vulnerable to climate change (Wall 1992, ACACIA 2000, IPCC 2001) and has received greater research attention. Climate change impact assessments of ski areas in a number of nations (Australia: Galloway 1988, König 1998; Austria: Breiling et al. 1997; Canada: McBoyle \& Wall 1992; Scotland: Harrison et al. 1999; Switzerland: König \& Abegg 1997, Elsasser \& Bürki 2002) all project negative consequences for the industry. An important limitation of these studies has been the incomplete consideration of snowmaking as a climate adaptation strategy. Snowmaking is an integral component of the ski industry and, as Scott et al. (2002) found, can have significant implications for the results of climate change impact assessments.

The objectives of this study were 3-fold. First, daily records of snow conditions and skiing operations for a primary ski area in the study area (southern Ontario, Canada) were examined in order to assess the sensitivity of ski areas to climate variability over a $17 \mathrm{yr}$ period and the importance of snowmaking as a climate adaptation. Second, ski conditions data were used to develop and calibrate a ski season simulation model capable of integrating both current and improved snowmaking capabilities to examine the potential impact of climate change (scenarios for the 2020s, 2050s, and 2080s) on the case study ski area. Third, the study explored how projected impacts on the ski industry differed under the wider range of climate change scenarios based on the IPCC Special Report on Emission Scenarios (SRES) (IPCC 2000).

\section{METHOD}

A schematic for the study methodology is provided in Fig. 1. The data sources utilized and the methodological procedures are specified sequentially in the remainder of this section.

\subsection{Study area and skiing data}

The Canadian alpine ski industry experienced significant growth from 1985 to 1995. In 1995 there were a total of 252 alpine ski areas operating across Canada and over 1.5 million active skiers during the 1999/2000 season (Canadian Ski Council 2000). Regionally, the province of Ontario contains the largest proportion of active Canadian skiers (30\%). The 40 members of the Ontario Snow Resorts Association (OSRA) reported 3.2 million skier visits during the 2000/01 ski season (M. Minardi, Ontario Snow Resorts Association, Barrie, Ontario, pers. comm. 2001). Toronto is Canada's largest city and greatest single market of active skiers (Canadian Ski Council 2000). The Canadian Ski Council (2000) reported that $45 \%$ of the skiers in this regional market travel less than $1 \mathrm{~h}$ to their ski area destination. Although ski areas near the City of Toronto are not among the internationally known Canadian ski resorts (e.g. Whistler-Blackcomb, Lake

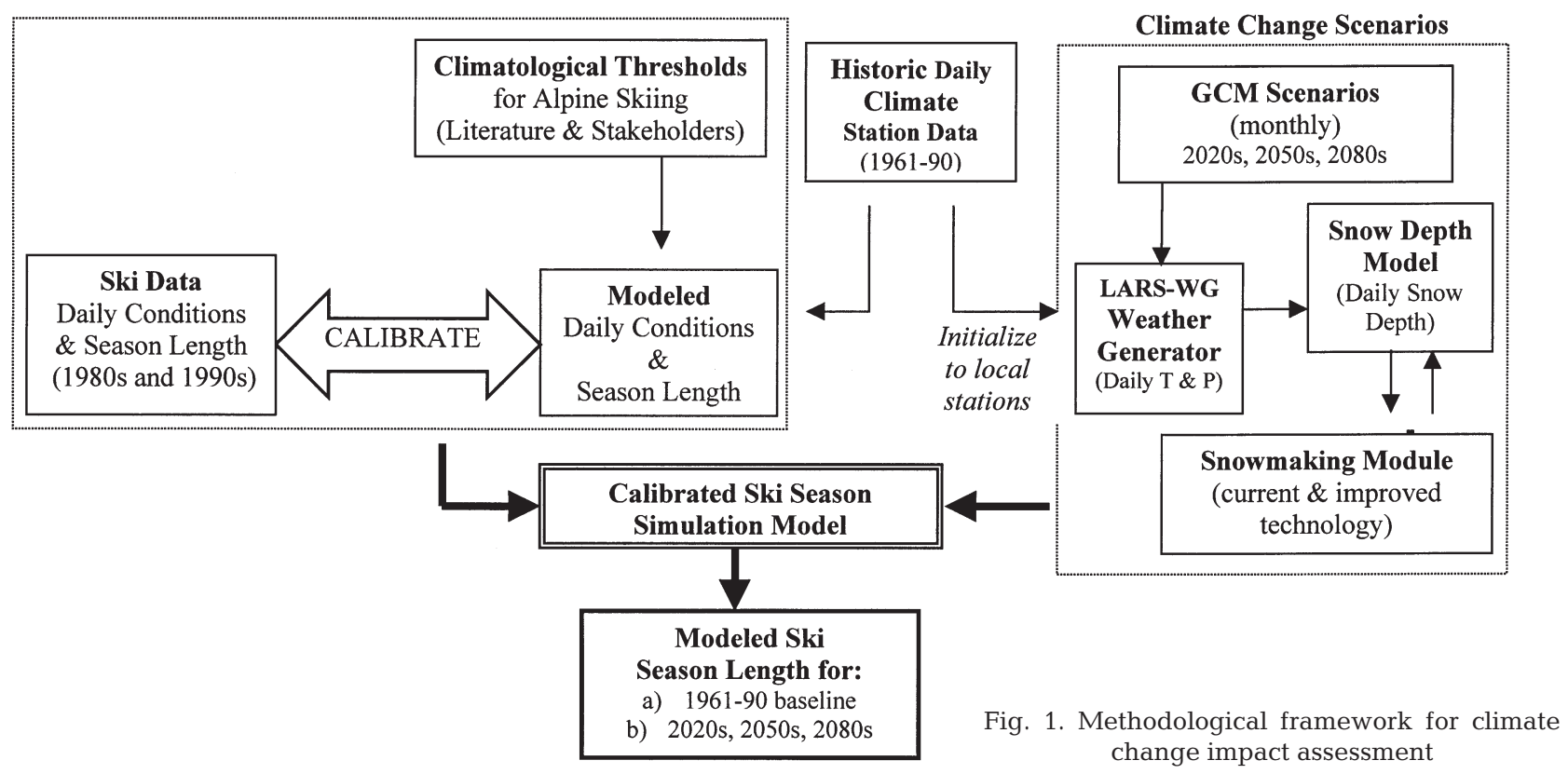


Louise, Mont Tremblant), they serve Toronto's large skiing market and, as McBoyle \& Wall (1992) suggested, have an important role in the development of skiing demand for the more challenging vacation ski resorts of North America and beyond.

Horseshoe Resort was the ski area chosen as the case study for this analysis because of its central location among other ski areas north of the City of Toronto and its business strategy of maximizing the length of the ski season (thereby displaying greater climate-related variability in ski season length than other ski areas that only open during the core ski season-approximately the Christmas holiday to the second week of March). Horseshoe Resort is located within a $1 \mathrm{~h}$ drive of the City of Toronto and attracts skiers from Toronto who want to ski for the day and return home in the evening ('day trip'). In order to best capture the Toronto daytrip ski market, the resort is known for its efforts to be the first ski area open in the region and the last to close. A CDN-\$5 million investment in a snowmaking system in the late 1980s has enabled Horseshoe Resort to consistently have the longest ski season in the region (averaging 124 d from 1980/1981 to 1999/2000).

Data on the daily ski conditions (including whether the ski area was in operation, snow depth, snow conditions, number of ski runs open, and snowmaking activities) for the winters of 1981/82-1999/2000 was provided by the Ontario Ministry of Tourism, Culture and Recreation.

\subsection{Climate data and climate change scenario construction}

The selection of the climate station for this study was based on 2 considerations: the proximity to Horseshoe Resort ski area, and the length of record and quality of individual climate stations. A complete record of daily temperature (maximum, minimum and mean), precipitation (rain and snowfall) and snow depth data for 1961-1996 (the last year the rehabilitated snow depth data set was available) was obtained for the Orillia climate station $\left(44.37^{\circ} \mathrm{N}, 79.25^{\circ} \mathrm{W} ; 220\right.$ masl) (Meteorological Service of Canada 1999, 2000). Two years with missing climate data during the potential ski season (November to April) were excluded from the 1961-1990 baseline calculations.

The climate change scenarios used in this analysis were obtained from the Canadian Climate Impact Scenarios (CCIS) Project. The scenarios provided by CCIS Project $^{1}$ have been constructed using recognised methodologies and in accordance with the recommendations of the Intergovernmental Panel on Climate Change (IPCC) Task Group on Scenarios for Climate Impact Assessment. The scenarios are derived from
30 yr means (2010-2039 corresponding to the scenario for the 2020s, 2040-2069 to the scenario for the 2050s, and 2070-2099 to the scenario for the 2080s) and represent change with respect to the 1961-1990 modeled baseline period. Monthly climate change scenarios from 6 modelling centres (using between 4 and 6 general circulation model [GCM] grid boxes depending on the resolution of the model) and forced with both IS92a and SRES emission scenarios (as available) were obtained for the study area. In order to consider a wide range of possible climate futures, yet limit the number of scenarios used in the analysis to a manageable number, scenarios that represented the upper and lower bounds of change in December-January-February (DJF) mean temperatures and precipitation were selected. The characteristics of the GCMs used in the analysis are outlined in Table 1, and their mean DJF temperature and precipitation changes are compared in Fig. 2.

To produce daily temperature and precipitation data for each of the climate change time series (2010-2039, 2040-2069 and 2070-2099), monthly climate change scenarios from the 6 GCM scenarios (Table 1) were downscaled using the LARS stochastic weather generator (Semenov et al. 1998), parameterized to the Orillia climate station using climate data from the baseline period 1961-1990. Stochastic weather generators such as LARS-WG are inexpensive computational tools that produce site-specific, multiple-year climate change scenarios at the daily timescale which incorporate changes in mean climate and climate variability as projected by GCMs (Semenov et al. 1998).

Temperature and precipitation variables were used to drive a locally calibrated snow depth model that was based largely on methods used to develop the Canadian Daily Snow Depth Database (Brown \& Braaten 1999) and Water Balance Tabulations for Canadian Climate Stations (Johnstone \& Louie 1983). This technique involved estimating 3 parameters: (1) amount of precipitation that falls as snow and rain, (2) snow accumulation, and (3) snowmelt. For this analysis a constant snow pack density of $300 \mathrm{~kg} \mathrm{~m}^{-3}$ was assumed (after Brown \& Braaten 1999). This is an acknowledged compromise, as the density of both natural snow and human-made snow can vary substantially and the ability to vary the density of snow during snowmaking is a considerable asset to ski areas. A US Army Corps of Engineers (1956) equation was used for daily snowmelt calculations:

$$
M=k[(1.88+0.007 R)(9 / 5 T)+1.27], \quad T>0
$$

\footnotetext{
${ }^{1}$ CCIS Project (2002) Canadian Climate Impact Scenarios Group, Meteorological Service of Canada, Regina. Available at http://www.ccis.uvic.ca/scenarios/
} 
Table 1. General circulation model (GCM) comparison. All scenarios include the forcing of greenhouse gases and atmospheric aerosols

\begin{tabular}{|c|c|c|c|c|c|}
\hline GCM & $\begin{array}{c}\text { Atmospheric } \\
\text { resolution } \\
(\text { degrees lat } \times \text { long) }\end{array}$ & $\begin{array}{l}\text { Atmospheric } \\
\text { layers }\end{array}$ & $\begin{array}{c}\text { Ocean } \\
\text { resolution } \\
(\text { degrees lat } \times \text { long })\end{array}$ & $\begin{array}{l}\text { Ocean } \\
\text { layers }\end{array}$ & $\begin{array}{l}\text { Emission } \\
\text { scenario }\end{array}$ \\
\hline $\mathrm{CGCM}^{\mathrm{a}}$ & $3.75 \times 3.75$ & 10 & $1.8 \times 1.8$ & 29 & IS92a $\mathrm{a}^{\mathrm{e}}$ \\
\hline $\mathrm{CGCM}^{\mathrm{a}}$ & $3.75 \times 3.75$ & 10 & $1.8 \times 1.8$ & 29 & SRES-B2 ${ }^{\mathrm{e}}$ \\
\hline HadCM3 $^{\text {b }}$ & $2.5 \times 3.75$ & 19 & $2.5 \times 3.75$ & 20 & IS92a, SRES-B2 \\
\hline $\mathrm{CCSR}^{\mathrm{c}}$ & $5.6 \times 5.6$ & 20 & $2.8 \times 2.8$ & 17 & IS92a \\
\hline $\mathrm{CSIRO}^{\mathrm{d}}$ & $3.2 \times 5.6$ & 9 & $3.2 \times 5.6$ & 21 & SRES-A2 \\
\hline \multicolumn{6}{|c|}{$\begin{array}{l}{ }^{a} \text { Canadian Centre for Climate Modelling and Analysis } \\
\text { bUK Hadley Centre for Climate Prediction and Research } \\
{ }^{c} \text { Centre for Climate System Research, University of Tokyo } \\
{ }^{d} \text { Australian Commonwealth Scientific \& Industrial Research Organization } \\
{ }^{e^{\prime}} \mathrm{X}^{\prime} \text { indicates ensemble average consisting of a number of scenarios undertaken with identical forcing scenarios, but slightly } \\
\text { different initial starting conditions in the atmosphere and oceans }\end{array}$} \\
\hline
\end{tabular}

where $M$ is snowmelt water $\left(\mathrm{mm} \mathrm{d}^{-1}\right), k$ is a locally calibrated snowmelt factor, $T$ is mean daily air temperature $\left({ }^{\circ} \mathrm{C}\right)$; and $R$ is mean daily rainfall (mm). Note: $T$ and $R$ were provided for each future time series (2010-2039, 2040-2069, 2070-2099) by output from the LARS weather generator.

The validity of the approach was tested using observed data from the 1980-1990 period at the Meteorological Service of Canada primary climate station in the study region (Muskoka station). The performance of the snow cover model versus observed snow depth at the Muskoka station is presented in Fig. 3. The snow cover model tended to have a deeper snow pack in the spring than the observed record. This is in part attributed to increased solar radiation in late March and early April. This over-prediction was not deemed problematic for this analysis as it occurs late in the ski season, when the ski areas in the study area have accumulated a large snow pack (usually $75 \mathrm{~cm}$ of packed

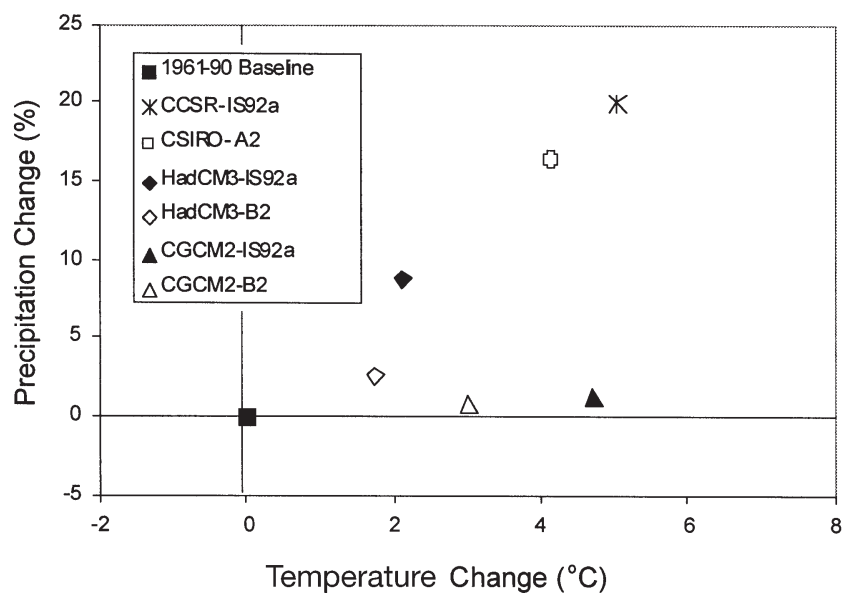

Fig. 2. Climate change scenario comparison (DJF 2050s) natural and human-made snow) and rely on this 'banked' snow during late-season operations. Typically, the demand for spring skiing in the study area wanes before the snow pack is exhausted.

To complete the ski area snow conditions modelling component, a snowmaking module was integrated with the snow depth model. The estimated technical capacities (e.g. minimum temperature at which snow can be made economically) and decision rules for the snowmaking module (e.g. when to start making snow to begin the ski season) were derived from communications with ski industry stakeholders in the study area and are summarized in Table 2. Anticipating technological improvements in snowmaking systems, the study also parameterized a snowmaking module with improved snowmaking capacities (Table 2).

With a vertical drop of less than $100 \mathrm{~m}$ (base $=312$ masl, summit $=406$ masl) differences in climate and snowmaking conditions at the top and bottom of the ski area were assumed to be minor and not modeled separately in this analysis.

\subsection{Ski season simulation model and calibration}

A number of climatological thresholds that define a 'skiable day' were identified in a literature review (Crowe et al. 1973, Lamothe \& Periard 1988). After comparing the thresholds against observed ski conditions and ski area operational activity in the study area, it was determined that these climatic thresholds were unsatisfactory for simulating ski seasons in the study area (Scott et al. 2002). In some cases, snow depth thresholds were unrealistic (e.g. $2.5 \mathrm{~cm}$ in Crowe et al. 1973). The thresholds for minimum and maximum temperature and precipitation were also exceeded frequently in the observed data. This is in part explained 


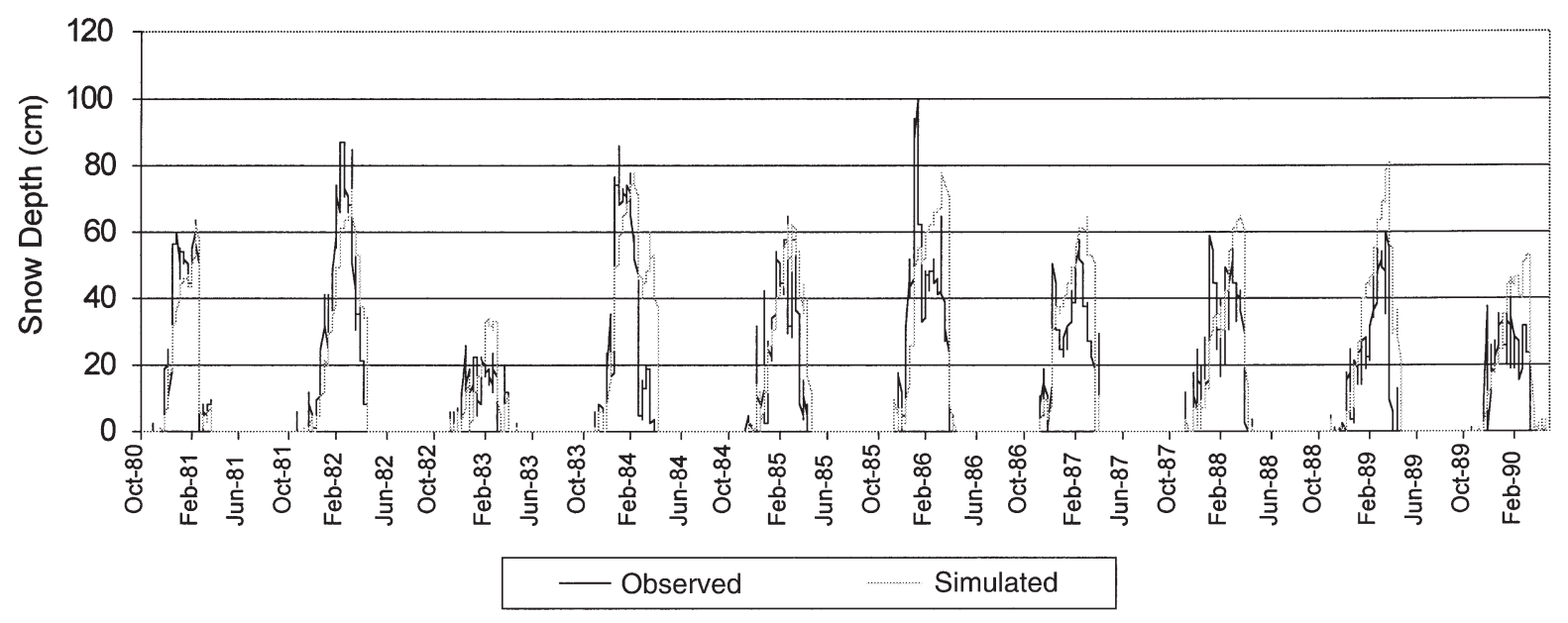

Fig. 3. Observed and simulated daily snow depth at Muskoka climate station 1980-1990. The Muskoka climate station is used for illustrative purposes because it is one of Environment Canada's primary climate stations and it is centrally located within the study area

by the different decision making of skiers (demand) and ski area management (supply). The former may choose not to ski when it is very cold or during poor snow conditions, but the latter must open to generate business revenue and accommodate those willing to accept sub-optimal conditions. The climate thresholds used to parameterize the ski season simulation model in this analysis were refined through examination of the observed ski operations data and communication with ski industry stakeholders. For the purposes of this study, ski areas were assumed to be closed if any of the following climatic conditions occurred: snow depth < $30 \mathrm{~cm}$; maximum temperature $>10^{\circ} \mathrm{C}$ for 2 consecutive days accompanied by liquid precipitation; or $2 \mathrm{~d}$ of liquid precipitation totalling $>20 \mathrm{~mm}$. A comparison of the observed and simulated ski seasons at the Horseshoe ski area revealed that over the $17 \mathrm{yr}$ of observed data that were available, the average season length was 124 and 123 d, respectively (minimum seasons were 111 and $99 \mathrm{~d}$ and maximum seasons 140 and 152 d). Overall the ski season simulation model performed reasonably, missing the observed season length by more than $7 \mathrm{~d}$ (approximately $5 \%$ of an average season) in only 5 of $17 \mathrm{yr}$.

A number of potential sources of error between the observed and simulated ski seasons exist. There could be small differences in climate records between the Orillia climate station and the Horseshoe Resort ski area (particularly for event-driven variables like snowfall). In one year there was a known inaccuracy in the reported ski conditions data; the Horseshoe Resort ski area was still open with a $55 \mathrm{~cm}$ snow base in early April, but the Ministry of Tourism stopped reporting ski conditions, thus shortening the observed season versus the simulated season. There are also potential sources of error related to the regional climate change projections provided by GCMs and the downscaling techniques utilized. Finally, an important difficulty in

Table 2. Snowmaking module technical capacities and decision rules

\begin{tabular}{|c|c|c|}
\hline & $\begin{array}{c}\text { Current snowmaking } \\
\text { technology }\end{array}$ & $\begin{array}{l}\text { Improved snowmaking } \\
\text { technology }\end{array}$ \\
\hline \multicolumn{3}{|l|}{ Technical capacity } \\
\hline Minimum temperature for efficient snowmaking $\left({ }^{\circ} \mathrm{C}\right)$ & -5 & -2 \\
\hline Snowmaking capacity $\mathrm{d}^{-1}$ over entire skiable terrain of ski area $(\mathrm{cm})$ & 10 & 15 \\
\hline \multicolumn{3}{|l|}{ Snowmaking decision rules } \\
\hline Snowmaking window & Nov 23-Mar 30 & Nov 23-Mar 30 \\
\hline Snow base depth to maintain ${ }^{\mathrm{a}}(\mathrm{cm})$ & 50 & 50 \\
\hline \multicolumn{3}{|c|}{$\begin{array}{l}\text { a Although } 30 \mathrm{~cm} \text { is the preferred minimum operational snow base and the climate suitability threshold used to simulate ski } \\
\text { season length, ski areas in the study region produce a thicker snow base (usually } 50-75 \mathrm{~cm} \text { ) early in the ski season in order } \\
\text { to have a reserve of snow in case of poor weather conditions (high temperatures, rain) later in the ski season. To emulate this } \\
\text { management strategy, the snowmaking module was designed to maintain a } 50 \mathrm{~cm} \text { snow base until the end of March (after } \\
\text { the economically important 'March-break' school holiday period in the study area) }\end{array}$} \\
\hline
\end{tabular}


attempting to model the ski season (which is a socioeconomic system) with only climate suitability criteria is the inability to account for business decision-making variables that also influence ski area operations. For example, ski area managers may not always abide by the decision-making rules that define our snowmaking module and decide to open the ski area with less than the preferred $30 \mathrm{~cm}$ snow base because a competitor has opened. Although we are able to qualitatively describe these potential sources of error in the methodology, we have not yet been able to quantify the degree of uncertainty associated with this modelling approach.

\section{CURRENT CLIMATE SENSITIVITY AND ADAPTATION}

The following regional newspaper headlines are illustrative of the sensitivity of the skiing industry in the study area to inter-annual climate variability: 'Warm temps killing ski season' (13 December 1998), 'Ski operators take big hit with warm weather' (29 March 2000), 'Skiing bonanza: early snow boosts Ontario resorts' (28 December 2000), 'Praying for a white Christmas: Warm weather has ski resort operators worried' (4 December 2001).

In order to reduce their vulnerability to climate variability, well-capitalized ski areas in the region have made multi-million dollar investments in snowmaking technology. As of 1977, only half of Ontario's ski areas had any type of snowmaking system in place (Lynch et al. 1981). However, in response to the poor ski seasons of 1979/1980 and 1982/1983, most ski areas made substantial improvements to their snowmaking systems

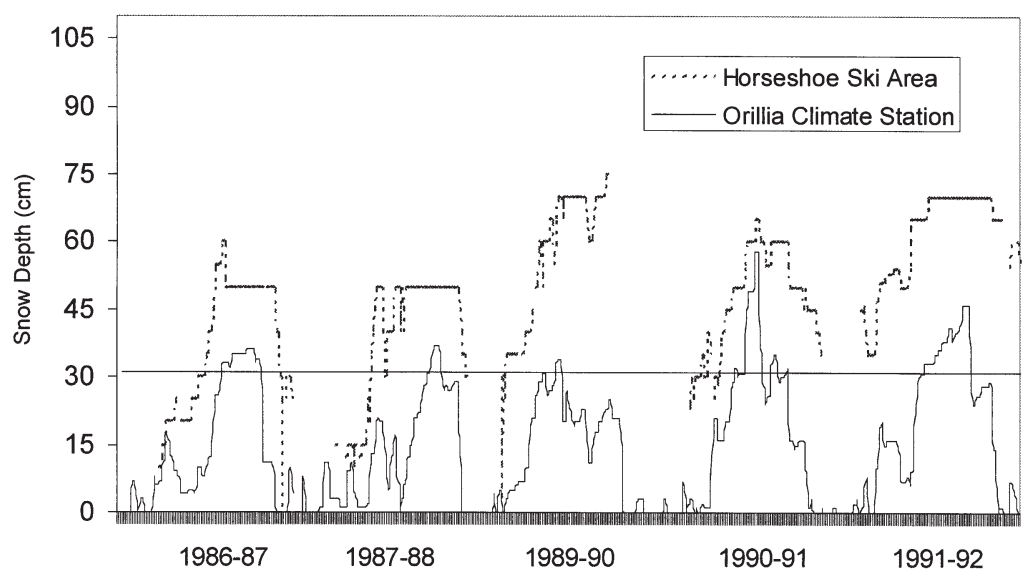

Fig. 4. Comparative snow depth at Orillia climate station (natural snow only) and Horseshoe ski area (natural snow and snowmaking). Ski areas in the study area cite a $30 \mathrm{~cm}$ snow base (solid line) as preferred for ski operations. Data unavailable for 1988/89 during the mid- to late 1980s. The former director of the Ontario Snow Resort Association emphasized the importance of snowmaking in the region when he stated (MacDonald 1988), 'If we had to rely on snow from the heavens, the ski industry would be bankrupt.' All of the ski areas in the region now have $100 \%$ snowmaking coverage of skiable terrain. This situation is similar to other non-alpine regions of Canada. All ski areas in the provinces of Québec and New Brunswick have snowmaking systems, although the proportion of skiable terrain covered by snowmaking varies (usually in the 50 to $90 \%$ range). However, the use of snowmaking is very different in alpine regions of Canada (the provinces of Alberta and British Columbia), where only 50 to $75 \%$ of ski areas have snowmaking systems and the proportion of skiable terrain covered is much lower.

The importance of snowmaking to Horseshoe Resort ski operations is clearly revealed in Fig. 4, where the recorded natural snow depth at the Orillia climate station is compared with the reported snow depth (composed of natural snow fall plus snowmaking) at the nearby Horseshoe Resort ski area. While some difference in snow depth could be the result of slightly different climatic conditions between the climate station and ski area, if this were the case, then one would expect to find periods where the ski area would have less snow. This is never the situation, and because we have documented records of snowmaking activity, we are confident that the majority of the difference in natural snow depth and snow depth at the ski area represents snowmaking activity. In the years illustrated, the absence of snowmaking would have meant that the preferred $30 \mathrm{~cm}$ snow base (solid line in Fig. 4) for ski operations would have been achieved for only a very short time. The economic viability of the ski area during these low snowfall winters would have been questionable without snowmaking systems. The multi-million dollar investment in snowmaking extended the period with an operational $30 \mathrm{~cm}$ snow base at the Horseshoe Resort ski area by 33 to $830 \%$ during the 1980 s and 1990s. Horseshoe Resort now has sufficient snowmaking capacity to make all of its ski runs operational (from a zero snow condition to a skiable base) with approximately $5 \mathrm{~d}$ of suitable temperatures.

\section{CLIMATE CHANGE IMPACT ASSESSMENT}

As indicated in Fig. 1, monthly temperature and precipitation climate 
change fields from GCMs were downscaled with the LARS weather generator (parameterized to local stations) to provide daily temperature and precipitation inputs into the snow cover model. When run without the snowmaking module, analysis of the modelled natural snow regime in the study area (days with snow cover and days with greater than $30 \mathrm{~cm}$ snow depth) revealed important changes under each of the climate change scenarios. The number of modelled days with a natural $30 \mathrm{~cm}$ snow base at Orillia climate station declined from an average of 71 in the modeled 1961-1990 baseline period to $7-43$ in the 2020s, 3-26 in the 2050s and 1-14 in the 2080s. While the depth of the snow base is only 1 climate suitability parameter used in ski season analysis, it is the most significant. As important as snowmaking was shown to be for the current viability of the ski industry in the study area (Section 3), the reduction in the number of days with a natural snow base of $30 \mathrm{~cm}$ suggests that by the 2020s the viability of the ski industry in the region would be in question without snowmaking. That was the conclusion of earlier studies that examined the potential impact of climate change on the ski industry in the region. In their analysis in the late 1980s and early 1990s, McBoyle \& Wall (1992) and Ordower (1995) projected 40 to $100 \%$ losses in the average ski season under 2 doubled carbon-dioxide $\left(\mathrm{CO}_{2}\right)$ equilibrium GCM scenarios. These studies were not able to account for the impact of the large investments in snowmaking systems that were taking place at the time. Today, the incorporation of snowmaking is a necessity for a robust climate change impact assessment of the ski industry in the study region.

The projected impact of climate change on the length of average ski season and snowmaking requirements at the Horseshoe Resort ski area differed substantially among the range of climate change scenarios selected for this analysis (Tables 3 \& 4). Unlike previous climate change impact studies of the skiing industry, this analysis was able to examine the impact of climate change scenarios for the early decades of this century, which are most relevant to business planning and investment time frames. In the 2020s, the HadCM3-B2 scenario projected that with current snowmaking technology there would be no change to the average ski season (relative to the 1961-1990 baseline) and relatively little additional snowmaking required (136\% of 1961-1990 baseline). The HadCM3-B2 scenario projects the least DJF warming in the study area of all the GCMs considered, with precipitation increases that help offset additional snow melt from slightly warmer average temperatures (Fig. 2). At the other end of the range of climate change projections for the 2020s, the warmer CGCM1-IS92a scenario projected a $16 \%$ reduction in the average ski season and a $144 \%$ increase in the amount of snowmaking required. With improved snowmaking technology (Table 2), the ski season loss in the 'worst-case' CGCM1-IS92a scenario for the 2020s could be only $8 \%$ with an approximate tripling ( $287 \%$ of $1961-1990$ baseline) in the amount of snow produced by snowmaking.

Although the CCSR-IS92a and CSIRO-A2 scenarios projected similar DJF warming as CGCM1-IS92a, the substantial increase in DJF precipitation in these 2 scenarios (20 and 16\%, respectively) offset projected ski season losses and additional snowmaking requirements.

Regardless of the climate change scenario, average ski seasons continue to shorten as the magnitude of climate change increases in the latter decades of the 21st century (Table 3). The impact of the different climate

Table 3. Modeled ski season length (\% change from 1961-1990 baseline). Modeled 1961-1990 baseline $=123 \mathrm{~d}$

\begin{tabular}{|lllllll|}
\hline $\begin{array}{l}\text { Climate change } \\
\text { scenario }\end{array}$ & \multicolumn{3}{c}{$\begin{array}{c}\text { Current } \\
\text { snowmaking } \\
\text { technology }\end{array}$} & \multicolumn{3}{c}{$\begin{array}{c}\text { Improved } \\
\text { snowmaking } \\
\text { technology }\end{array}$} \\
& 2020s & 2050 s & 2080s & 2020s & 2050 s & 2080 s \\
\hline CGCM1-IS92a & -16 & -32 & -48 & -8 & -21 & -35 \\
HadCM3-IS92a & -9 & -19 & -37 & -3 & -11 & -26 \\
CCSR-IS92a & -11 & -21 & -45 & -4 & -15 & -32 \\
CSIRO-A2 & -9 & -19 & -50 & -3 & -11 & -39 \\
CGCM2-B2 & -5 & -9 & -19 & 0 & -3 & -11 \\
HadCM3-B2 & 0 & -7 & -11 & +5 & -1 & -4 \\
& & & & & & \\
\hline
\end{tabular}

Table 4. Modeled snowmaking requirements (\% of 1961-1990 baseline). Modeled 1961 -1990 baseline $=56 \mathrm{~cm}$

\begin{tabular}{|c|c|c|c|c|c|c|}
\hline \multirow[t]{2}{*}{ Climate change } & \multicolumn{3}{|c|}{$\begin{array}{c}\text { Current } \\
\text { snowmaking } \\
\text { technology }\end{array}$} & \multicolumn{3}{|c|}{$\begin{array}{l}\text { Improved } \\
\text { snowmaking } \\
\text { technology }\end{array}$} \\
\hline & $2020 s$ & $2050 s$ & $2080 s$ & $2020 s$ & $2050 s$ & $2080 s$ \\
\hline CGCM1-IS92a & 244 & 342 & 380 & 287 & 421 & 521 \\
\hline HadCM3-IS92a & 160 & 214 & 312 & 187 & 262 & 425 \\
\hline CCSR-IS92a & 205 & 275 & 401 & 248 & 342 & 519 \\
\hline CSIRO-A2 & 171 & 253 & 380 & 198 & 307 & 542 \\
\hline CGCM2-B2 & 162 & 200 & 267 & 183 & 230 & 317 \\
\hline HadCM3-B2 & 136 & 161 & 191 & 148 & 185 & 230 \\
\hline
\end{tabular}



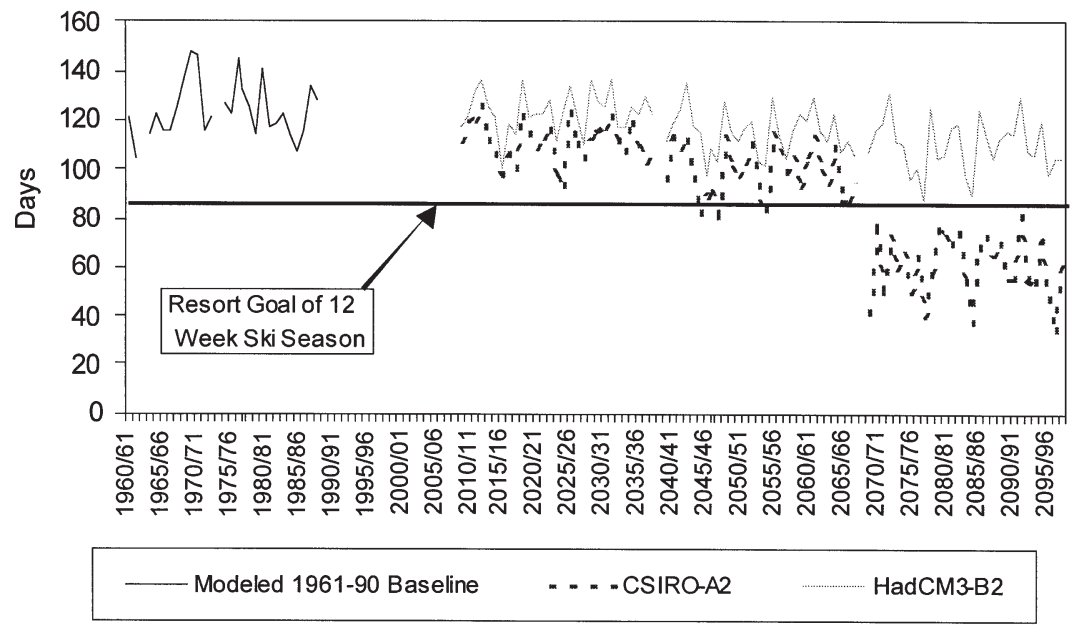

Fig. 5. Modeled ski season length with current snowmaking capabilities. Years with missing climate data not included

from 1980-1999 and the modeled 1961-1990 baseline, this economic benchmark was achieved every year. Assuming no change in snowmaking capabilities, the probability of a $12 \mathrm{wk}$ ski season in the 2020s remained $100 \%$ in all climate change scenarios except the CGCM1-IS92a and HadCM3-IS92a scenarios, where the probability dropped to 93 and $97 \%$, respectively (though both became $100 \%$ with improved snowmaking capabilities). By the 2050s, the probability of a 12 wk ski season with current snowmaking capacities remained $100 \%$ in only the 2 SRES-B2-driven scenarios (HadCM3-B2 and CGCM2B2). With improved snowmaking capabilities, 3 of the 4 remaining scenarios achieved $100 \%$ probability in

change scenarios on the ski season and snowmaking requirements also becomes much more pronounced in the 2050s and 2080s, with 2 distinct futures emerging. Throughout each time period, the HadCM3-B2 scenario remains the 'best-case' scenario, with only an $11 \%$ reduction in the length of the average ski season by the 2080 s (only a $4 \%$ reduction with improved snowmaking technology). The other climate change scenario driven with the SRES-B2 emission scenario (CGCM2-B2) projected slightly larger, but comparable, losses in average ski seasons in the 2080s $(19 \%$ with current snowmaking technology and only $11 \%$ with improved snowmaking technology in place).

The 4 remaining climate change scenarios driven with IS92a and SRES-A2 emission scenarios (CGCM1-IS92a, HadCM3-IS92a, CCSR-IS92a and CSIRO-A2) projected a distinctly different and more challenging future for the ski industry in the study area. With current snowmaking capabilities, these 4 climate change scenarios projected a 37 to $50 \%$ reduction in the average ski season in the 2080s (Table 3). Additional snowmaking requirements more than tripled in each of these 2080s scenarios (ranging from 312 to $401 \%$ of the 1961-1990 baseline). With improved snowmaking capabilities, projected losses in the average ski season in the 2080s were reduced to $26-39 \%$ under these same 4 climate change scenarios. The estimated additional snowmaking requirements increased to between 425 and 542\% (relative to the 1961-1990 baseline).

Fig. 5 displays the trend in the projected ski season length under the overall 'best-case' HadCM3-B2 and 'worst-case' CSIRO-A2 scenarios and whether or not a ski season achieved the stated business objective of a minimum 12 wk (84 d) season (as indicated by Horseshoe Resort management). During the observed record the 2050s. The relatively drier CGCM1-IS92a scenario was the exception, with only an $83 \%$ probability using improved snowmaking capabilities. The differentiation between the SRES-B2 driven scenarios and the other scenarios was very prominent in the 2080s. The SRES-B2 scenarios achieved a 12 wk ski season every year, while the probability among the other 4 scenarios dropped to between $31 \%$ (CSIRO-A2) and 69\% (HadCM3-IS92a). It would appear that by the 2080s, an important vulnerability threshold is surpassed in the IS92a and SRES-A2 driven scenarios, where projected warming can no longer be offset by increased winter precipitation or improved snowmaking capabilities. In the 'worst-case' CSIRO-A2 scenario, the probability of achieving a 12 wk ski season with current snowmaking capacities declined from $90 \%$ in the 2050 s to $0 \%$ in the 2080 s. With improved snowmaking capacity the probability declined from $100 \%$ in the 2050 s to $31 \%$ in the 2080 s.

\section{DISCUSSION}

The findings of this study were consistent with previous climate change impact assessments of the skiing industry, in that the scenarios utilized indicate an increasingly challenging business environment for the ski industry under climate change. In contrast, however, the magnitude of the projected climate change impact was substantially diminished relative to previous studies because the research was able to incorporate snowmaking as a climate adaptation and examine a wider range of climate futures (SRES) that only recently became available through the IPCC and international climate modelling centres. In this study, 
approximate doubled-atmospheric $\mathrm{CO}_{2}$ equivalent scenarios (2050s) reduced the average ski season with current snowmaking capabilities between $7 \%$ (HadCM3-B2) and 32\% (CGCM1-IS92a) and 1\% (HadCM3-B2) and 21\% (CGCM1-IS92a) with improved snowmaking capabilities. These scenarios are more optimistic than earlier studies that estimated a 40 to $100 \%$ loss of the ski season in the study area under doubled- $\mathrm{CO}_{2}$ conditions (McBoyle \& Wall 1992, Ordower 1995). The findings clearly demonstrate the importance of snowmaking as a climate adaptation and that the value of investments in snowmaking systems will only increase under climate change. These more optimistic findings must be tempered with the possibility that the extra costs of making additional amounts of snow at warmer average temperatures (which increases the energy use and cost of snowmaking) may reach a threshold that becomes uneconomic.

The different vulnerability of the ski season to the range of climate change scenarios illustrated that achieving an SRES-B2 world future is in the best interest of the ski industry in this region of Canada. Characterized by increased concern for environmental and social sustainability, the SRES-B2 scenario is among the lower estimates of projected global climate change (see IPCC 2000 for a full explanation of the SRES scenarios) and for this reason, this scenario is also in the interests of the global skiing and winter tourism industry as well. Programs such as the 'Sustainable Slopes Charter' of the National Ski Areas Association ${ }^{2}$ in the United States should be further promoted as part of a near-term global climate change mitigation response by the global skiing industry. Innovative initiatives such as Aspen Skiing Company's ${ }^{3}$ corporate policy statement on climate change and related program of energy efficiency retrofits are to be particularly encouraged.

While this study made important advances in terms of understanding the importance of snowmaking as a climate adaptation by ski areas in southern Ontario (Canada), a number of additional areas of inquiry are required in order to understand more fully the vulnerability of the skiing industry in this region to climate change. To determine the net economic impact of climate change at Horseshoe Resort and other regional ski areas would require a more detailed analysis of several factors, including the following: the costs of additional snowmaking; the relative impact of climate

\footnotetext{
${ }^{2}$ Sustainable slopes: the environmental charter for ski areas. National Ski Areas Association (2002). Available at http:// www.nsaa.org/environ/charter2k.pdf

${ }^{3}$ Policy statement-corporate position on climate change (2001). Available at http://www.aspensnowmass.com/ environment/programs/climate_policy.cfm
}

change on competitors and resultant changes in intraand inter-regional skiing market share; how adaptation by skiers could alter skiing demand; and the effect of other adaptation strategies such as business diversification and weather derivatives/insurance.

Snowmaking costs represent a significant share of operating expenses at ski areas in Southern Ontario and elsewhere in North America. The cost of snowmaking varies at individual ski areas on the basis of the efficiency of the snowmaking system in place, electricity and human resources costs, and climatic conditions (temperature, humidity, wind). Ski area managers have the detailed knowledge of their ski operations necessary to determine whether projected increases in snowmaking operational costs or additional investments in snowmaking infrastructure are economical. Assessments of the implications of climate change for ski area operations and infrastructure investments are likely to become more common as ski area managers in the study area indicated that financial institutions have begun to discuss climate change during financing negotiations. The 2020s scenarios developed in this study have been positively received by ski industry stakeholders, as they are more relevant to their business planning and investment time horizons than the previously available doubled $-\mathrm{CO}_{2}(\sim 2050$ s) scenarios.

To assess the business impact of climate change at any ski area in southern Ontario, the relative impact of climate change on neighbouring winter recreation destinations will also need to be examined. Climate change is likely to alter the competitive relationship between ski areas in the region, as some will be climatically advantaged (higher elevation, north-facing slopes, lower average humidity) or better able to adapt (more advanced and efficient snowmaking system, more diversified business operations, better capitalized). The potential elimination of competitors would increase market share for remaining ski areas in the region. This is equally true of competitive relationships between larger ski regions. If the magnitude of climate change impacts in Québec, Michigan and Vermont are such that more Ontario skiers stay within the province or skiers from those regions increasingly visit Ontario, the market share of Ontario ski areas may increase despite slightly reduced ski seasons. Further analysis of the potential impact of climate change on the major ski areas of North America is required for insight into the potential economic impact of climate change for the ski industry and winter tourism patterns.

Another important issue related to additional snowmaking requirements projected in this analysis is the continued availability of suitable water supplies. The major ski areas in the study area have typically developed on-site reservoirs or have access to other large sources of water (e.g. the Blue Mountain ski area has 
built a pipeline to Lake Huron, one of the 5 Great Lakes). Water used to make snow for ski areas melts and returns to the same watershed in spring, so that the only net water withdrawal is through evaporative losses. Consequently, the impact of additional snowmaking in the future is not seen to be a critical water resource issue in this region and less of a concern than additional irrigation requirements for golf courses, for example. Water resource allocation for snowmaking is, however, a more salient issue for other areas of Canada and for international alpine ski regions.

The current understanding of how recreational users and tourists respond to climate variability (whether or not to participate or purchase equipment, activity substitution, use patterns, destination choice) is very limited. Only König (1998) has explored the potential impact of climate change for skiing demand. Skiers of different skill levels indicated they would respond differently to projected climate change impacts on ski areas in Australia (König 1998). Half of high-skill skiers indicated they would travel to other locations in the world for quality skiing conditions. Only $18 \%$ of low-skill skiers would incur the expense of international travel to ski, and a similar number $(16 \%)$ indicated they would give up skiing altogether if the impact scenario provided to them occurred. The potential response of Ontario skiers to projected changes in ski season length and snow conditions is an important uncertainty. For example, if people adjust their recreational behaviour and ski more frequently in a shorter season, business revenues could remain the same or increase even with a shortened ski season. Additional research on the impacts of climate change for recreation and tourism demand is required to improve estimates of the potential economic impact within the ski industry.

Business diversification is an important climate adaptation strategy for ski areas. Horseshoe Resort has transformed itself from a ski resort to a 4-season resort operation by diversifying into golf and other summerseason recreation. In order to examine the net economic impact of changes in the ski season and higher snowmaking costs on the resort, these impacts would have to be considered in the context of overall resort operations. For example, increased revenues from an extended golf season might offset any potential losses related to reductions in the ski season.

Another important adaptation strategy that ski areas should consider strongly is the emerging market for weather derivatives and weather insurance (Conley 1999, Zeng 2000). A weather derivative is essentially a contract between 2 parties that stipulates what payment will occur as a result of the meteorological conditions that occur during the contract period specified. Weather derivatives are highly flexible instruments that can be based on a wide range of meteorological variables (temperature, precipitation, sunshine, snow and ice conditions) and temporal periods (a $1 \mathrm{wk}$ festival or recreational event, weekends during the summer months, the ski season, etc.). Weather-derivative contracts can be structured to reduce the weatherrelated risk of a range of tourism and recreation businesses. For example, a ski area could establish a weather-derivative contract based on a specified number of days in the critical Christmas-New Year period with adequate snowmaking temperatures or amount of natural snowfall.

Climate variability and change is a challenge to the tourism industry that has not been adequately assessed. The emergence of the weather-derivative market to reduce weather-related business risks and the consideration of climate change by financial institutions during financing negotiations with winter tourism operators may signal a short-term need to better understand the vulnerability of winter recreation and tourism to climate variability and change, and to facilitate necessary collaboration between the tourism industry and applied climatologists.

Acknowledgements. The authors are grateful to all of the tourism and recreation sector stakeholders who gave time and insight to the project and the Government of Canada's Climate Change Action Fund for partially funding the project. The authors would also like to thank the Ontario Ministry of Tourism for the provision of ski conditions data, Elaine Barrow (Environment Canada) for climate change scenario data, Mikhail Semenov (University of Bristol, UK) for the use of the LARS-Weather Generator, Brenda Jones and Nancy Wun (Faculty of Environmental Studies, University of Waterloo) for data collection and processing, and the helpful comments of 3 anonymous referees.

\section{LITERATURE CITED}

ACACIA (2000) Tourism and recreation. In: Parry M (ed) Assessment of potential effects and adaptations for climate change in Europe. Jackson Environment Institute, University of East Anglia, Norwich, p 217-226

Agnew M, Viner D (2001) Potential impact of climate change on international tourism. Tourism Hospitality Res 3:37-60

Breiling M, Charamza P, Skage O (1997) Klimasensibilität Österreichischer Bezirke mit besonderer Berücksichtigung des Wintertourismus. Report 97:1. Institute for Landscape Planning, Alnarp

Brown RD, Braaten RO (1999) Spatial and temporal variability of Canadian monthly snow depths, 1946-1995. Atmos Ocean 36(1):37-54

Canadian Ski Council (2000) 1999/2000 Canadian skier and snowboarder survey. Canadian Ski Council, Mississauga

Conley J (1999) Climate control. Risk Manage 46:1-16

Crowe RB, McKay GA, Baker WM (1973) The tourist and outdoor recreation climate of Ontario, Vol 1. Objectives and definitions of seasons. Atmospheric Environment Service, Environment Canada, Toronto

Elsasser H, Bürki R (2002) Climate change as a threat to tourism in the Alps. Clim Res 20:253-257 
Galloway RW (1988) The potential impact of climate changes on Australian ski fields. In: Pearman GI (ed) Greenhouse: planning for climatic change. CSIRO, Melbourne, p 428-437

Harrison SJ, Winterbottom SJ, Sheppard C (1999) The potential effects of climate change on the Scottish tourist industry. Tourism Manage 20:203-211

IPCC (2000) Emission scenarios. A special report of IPCC Working Group 3. Summary for policy makers. IPCC, Geneva

IPCC (2001) United Nations Inter-governmental Panel on Climate Change, Third Assessment Report, North American Chapter, Tourism and Recreation (15.2.6). IPCC, Geneva, p 769-770

Johnstone K, Louie P (1983) Water balance for Canadian climate stations. Report DS\#8-83, Atmospheric Environment Service, Environment Canada, Toronto

König U (1998) Tourism in a warmer world: implications of climate change due to enhanced greenhouse effect for the ski industry in the Australian Alps. Wirtschaftsgeographie und Raumplanung, Vol 28. University of Zurich

König U, Abegg B (1997) Impacts of climate change on tourism in the Swiss Alps. J Sustainable Tourism 5(1):46-58

Lamothe \& Periard (1998) Implications of climate change for downhill skiing in Quebec. Climate Change Digest 88-03, Environment Canada, Ottawa

Lynch P, McBoyle G, Wall G (1981) A ski season without snow. In: Phillips D, McKay G (eds) Canadian climate in review - 1980. Environment Canada, Ottawa, p 45-52

MacDonald J (1988) Boom time on hills as skiing becomes a megabucks sport. Toronto Star, 22 December, D6

Maddison D (2001) In search of warmer climates? The impact of climate change on flows of British tourists. Clim Change 49:193-208

McBoyle GR, Wall G (1992) Great lakes skiing and climate change. In: Gill A, Hartmann R (eds) Mountain resort development. Centre for Tourism Policy and Research,

Editorial responsibility: Andrew Comrie,

Tucson, Arizona, USA
Simon Fraser University, Burnaby, p 70-81

Meteorological Service of Canada (1999) Canadian daily climate data - Ontario 1999. CD-ROM, Meteorological Service of Canada, Downsview, Ontario

Meteorological Service of Canada (2000) Canadian snow data. CD-ROM, CRYSYS Project, Climate Processes and Earth Observation Division, Meteorological Service of Canada, Downsview, Ontario

Ordower M (1995) Investigating the sensitivity of downhill skiing in southern Ontario to climate change. Cooperative Education Work Report, Department of Geography, University of Waterloo, Waterloo

Perry AH (1997) Recreation and tourism. In: Thompson RD, Perry AH (eds) Applied climatology. Routledge, London, p 240-248

Scott D, Jones B, Lemieux C, McBoyle G, Mills B, Svenson S, Wall G (2002) The vulnerability of winter recreation to climate change in Ontario's Lakelands Tourism Region. Occasional Paper 18, Department of Geography Publication Series, University of Waterloo, Waterloo

Semenov MA, Brooks RJ, Barrow EM, Richardson CW (1998) Comparison of the WGEN and LARS-WG stochastic weather generators in diverse climates. Clim Res 10: 95-107

Smith K (1990) Tourism and climate change. Land Use Policy April:176-180

Smith K (1993) The influence of weather and climate on recreation and tourism. Weather 48:398-404

US Army Corps of Engineers (1956) Snow hydrology. US Army Corps of Engineers, Portland, OR

Wall G (1992) Tourism alternatives in an era of global climate change. In: Smith V, Eadington W (eds) Tourism alternatives. University of Pennsylvania Press, Philadelphia, p 194-236

Zeng L (2000) Weather derivatives and weather insurance: concept, application and analysis. Bull Am Meteorol Soc 81:2075-2082

Submitted: August 21, 2002; Accepted: November 14, 2002 Proofs received from author(s): January 10, 2003 